\title{
Correlations between mother's knowledge level of exclusive breastfeeding and the pattern in the 6-month child in Posyandu of Jatimulyo Village, Petanahan Sub- District, Kebumen Regency, Central Java, Indonesia
}

\author{
Hastin Ika Indriyastuti ${ }^{1^{*}}$, Wuri Utami ${ }^{2}$, Juad Juad ${ }^{2}$ \\ ${ }^{1}$ Midwifery Program, Sekolah Tinggi Ilmu Kesehatan Muhammadiyah, Gombong, Central \\ Java, Indonesia \\ ${ }^{2}$ Nursing Program, Sekolah Tinggi IImu Kesehatan Muhammadiyah, Gombong, Central \\ Java, Indonesia
}

*Correspondence: hastin.myu@gmail.com. Telp: +6285292234445

Received 05 May, 2020; Accepted 25 June, 2020; Published 26 June, 2020

\begin{abstract}
Background: Globally, the infant mortality rate (IMR) is still extremely high. One of the efforts to improve children's health is exclusive breastfeeding for six months. Exclusive breastfeeding can reduce infant mortality rate caused by various infectious diseases. Thus, the community, especially mothers need to have proper knowledge about exclusive breastfeeding, and then they are expected to practice it. This study aims to determine the relationship between mothers' knowledge of exclusive breastfeeding and the breastfeeding patterns of 6-month children in Jatimulyo Village, Petanahan Sub-district, Kab, Indonesia. Kebumen Regency, Central Java Province, Indonesia.

Methods: The study was conducted in Jatimulyo Village using quantitative methods and correlation design with a cross-sectional approach. This study sample consisted of 56 mothers who had children aged 6-24 months selected based on the total sampling approach. Data were analyzed using univariate analysis and bivariate analysis using chi-square statistical tests.
\end{abstract}

Results: This study found that most of the respondents are 26-30 years old and have a high school education level with multigravida parity and have a moderate level of knowledge. The study showed a relationship between the level of exclusive breastfeeding knowledge and breastfeeding patterns with a p-value of $0.002(<0.05)$ and a correlation value of 0.499 .

Conclusions: Therefore, it can be concluded that there is a relationship between the level of knowledge about exclusive breastfeeding and breastfeeding patterns with a p-value of 0.002 $(<0.05)$ and a correlation value of 0.499 .

Keywords: Mothers' knowledge, breastfeeding pattern, baby nutrition, exclusive breastfeeding

\section{INTRODUCTION}

One of the efforts to improve children's health is by providing exclusive breastfeeding for six months of inborn babies. Exclusive breastfeeding can reduce infant mortality rate caused by common infectious diseases in children such as diarrhea and pneumonia. Moreover, 


\section{Epidemiology and Society Health Review $\mid \mathbf{E S H R}$}

exclusive breastfeeding can accelerate the recovery from an illness (1). Without exclusive breastfeeding, children will quickly get diarrhea 30 times higher than those receiving exclusive breastfeeding, even though they have higher risks of death due to malnutrition (2). Breast milk is beneficial for infant to support their lives, such as immunological, psychological, intelligence, and neurological, while for mothers, it can be a method for controlling pregnancy (3).

Indonesia's national health survey (Susenas) data show that one in two infants aged 0-5 months receives exclusively breastfeeding (4). The percentage of infants receiving exclusive breastfeeding in rural areas is higher than in urban areas, namely $57.22 \%$, compared to $54.77 \%$ (4). The achievement of exclusive breastfeeding in Kebumen District is $66.95 \%$ (5). It has not met the government's target yet, as stated in the Decision of the Ministry of Health Number 450/Menkes/SK/IV/2004 concerning the exclusive breastfeeding target in Indonesia, $80 \%$. Thus, it can be said that exclusive breastfeeding has not yet reached the goal (3).

Many factors affect the success of exclusive breastfeeding. A study revealed that mothers whose husbands support exclusive breastfeeding would succeed in practicing it twice as much as those without husbands' support (6). In other studies, education, knowledge, and experience of the mother become a predisposing factor affecting exclusive breastfeeding, and the support of health workers becomes a motivating factor for exclusive breastfeeding (7). World Health Organization (WHO) divides breastfeeding patterns into three: sole, predominant, and partial breastfeeding. Exclusive breastfeeding is providing breast milk from birth until six months without any supplementary food except vitamins and both oral and injection medicine. The predominant pattern of breastfeeding is to give water or others before the milk comes out. In contrast, the partial pattern provides complementary foods such as formula milk, water, porridge, or other foods before the baby is six months old, either continuously or pre-reactively (8).

Based on previous research shows there was a relationship between exclusive breastfeeding knowledge and provision of complementary foods (MPASI) for infants aged 6-12 months in the coverage areas of Puskemas Samigaluh II. Most mothers who provide MPASI have a secondary education level and are aged 20-40 years with multigravida and do not work or housewives. Mothers with a moderate knowledge level of exclusive breastfeeding do not provide MPASI (9).

Based on the preliminary study conducted in April 2019 in Petanahan Sub-district, Jatimulyo village has the lowest exclusive breastfeeding level in 2018 , with only $30 \%$. Jatimulyo village has 4 RWs (a unit area under village) with seven integrated health services post (Posyandu) and 56 mothers with children aged 6-24 months. A total of 3 out of 8 interviewed mothers practice exclusive breastfeeding, and 5 out of 8 interviewed mothers used a partial pattern in breastfeeding. The reasons for using partial patterns include feeling tired to get up in the middle of the night to breastfeed, low breast milk production, and working.

Based on the mentioned background, we formulated a research question "is there a relationship between the mother's level of knowledge about the exclusive breastfeeding pattern in a 6-month-old child in Posyandu of Jatimulyo village". Given the importance of exclusive breast milk, authors want to know if the knowledge is the underlying of exclusive breastfeeding.

\section{METHODS}

This quantitative research used a correlation research design with a cross-sectional approach. It aims to link a variable with another. The researchers only observed and measured variables at one particular time. The measurement was not limited to one time 
simultaneously, but each subject was only subjected to one measurement without any repetition (6). Subjects were measured for their knowledge of exclusive breastfeeding and associated with the breastfeeding patterns. We used a knowledge questionnaire adopted from the Tri Hartatik study that had been tested for validity (10).

The study applied a total sampling technique with 56 respondents with children aged 6-24 months in 7 integrated health services post in Jatimulya Village, Petanahan Sub-district. Data were analyzed using univariate and bivariate analysis.

\section{RESULTS}

\section{Respondents Characteristic}

Thirty-nine of respondents $(69.7 \%)$ are $26-30$ years old. A total of 30 respondents $(53.6 \%)$ have senior high education levels. Most of them (35 respondents or $62.5 \%$ ) parity status is multigravida (Table 1)

Table 1. Demographic characteristic of respondents

\begin{tabular}{llll}
\hline Variable & Characteristics & $\mathbf{N}=\mathbf{5 6}$ & Percent (\%) \\
\hline Age (year) & $17-25$ & 12 & 21.4 \\
& $26-35$ & 39 & 69.7 \\
& $36-45$ & 5 & 8.9 \\
\cline { 2 - 4 } Education & Total & 56 & 100 \\
& PS & 5 & 8.9 \\
& JHS & 17 & 30.4 \\
& SHS & 30 & 53.6 \\
& University & 4 & 7.1 \\
\cline { 2 - 4 } Parity & Total & 56 & 100 \\
& Primigravida & 21 & 37.5 \\
& Multigravida & 35 & 62.5 \\
\cline { 2 - 4 } & Total & 56 & 100 \\
\hline
\end{tabular}

Table 2 shows that 40 respondents (71.4\%) have a moderate level of exclusive breastfeeding knowledge.

Table 2. Distribution frequency of respondents based on knowledge of exclusive breastfeeding in Jatimulyo Village, June 2020

\begin{tabular}{ccc}
\hline $\begin{array}{c}\text { Knowledge of exclusive } \\
\text { breastfeeding }\end{array}$ & $\mathbf{N}=\mathbf{5 6}$ & Percent (\%) \\
\hline High & 12 & 21.4 \\
Moderate & 40 & 71.4 \\
Low & 4 & 7.2 \\
\hline Total & 56 & 100 \\
\hline
\end{tabular}




\section{Epidemiology and Society Health Review $\mid \boldsymbol{E S H R}$}

Table 3 shows that a total of 24 respondents $(42.9 \%)$ practice predominant breastfeeding patter.

Table 3. The frequency distribution of respondents based on breastfeeding patterns in Jatimulyo Village, Petanahan Sub-district, June 2020

\begin{tabular}{lll}
\hline Breastfeeding patterns & $\mathbf{N}=\mathbf{5 6}$ & Percent (\%) \\
\hline Exclusive & 21 & 37.5 \\
Predominant & 24 & 42.9 \\
Partial & 11 & 19.6 \\
\hline Total & 56 & 100 \\
\hline
\end{tabular}

Table 4 shows that most respondents have a moderate level of knowledge of exclusive breastfeeding with the breastfeeding pattern varied from exclusive (12 respondents or $21.4 \%$ ), predominant (20 respondents or $35.7 \%$ ), and partial (8 respondents or $14.3 \%$ ).

Table 4. The relationship between the level of knowledge about exclusive breastfeeding and breastfeeding patterns in Jatimulyo Village, Petanahan Subdistrict, June 2020

\begin{tabular}{llllll}
\hline \multirow{2}{*}{$\begin{array}{l}\text { Knowledge of exclusive } \\
\text { breastfeeding }\end{array}$} & \multicolumn{5}{c}{ Breastfeeding pattern } \\
\cline { 2 - 5 } & Exclusive & Predominant & Partial & $\mathbf{r}$ & $\boldsymbol{p}$ \\
\cline { 2 - 5 } & $\mathrm{N}(\%)$ & $\mathrm{N}(\%)$ & $\mathrm{N}(\%)$ & \\
\hline High & $9(16)$ & $3(35.4)$ & $0(0)$ & 0.499 & 0,002 \\
Moderate & $12(21.4)$ & $20(35.7)$ & $8(14.3)$ & \\
Low & $0(0)$ & $1(1.8)$ & $3(5.4)$ & \\
\hline Total & 21 & 24 & 11 & \\
\hline
\end{tabular}

$r=$ coefficient correlation; $p=p$-value

The Chi-square test result shows the correlation coefficient value of 0.499 with a $p$-value of $0.002(<0.05)$. Therefore, it can be concluded that there is a significant relationship between mothers' exclusive breastfeeding and breastfeeding patterns in 6-month-old children at Jatimulyo Village, Petanahan Sub-district.

\section{DISCUSSIONS}

This research found that mothers aged 26-30 years are not fully aware of the importance of exclusive breastfeeding. Individuals in this age group are mature enough and able to manage family and children (11). According to previous research shows the relationship between the age of mothers and the giving of exclusive breast milk with the value $P=0,026$ $(<0.05)(12)$. The study in Jatimulyo village obtained that the respondents with sufficient knowledge in early adulthood due to lack of breast milk experience and were also influenced by cultural cultures still detrimental.

Based on the research result, a person's education level will affect the level of knowledge. The higher education, the higher awareness of the importance of exclusive breastfeeding and vice versa (11). The result of the study in Jatimulyo Village revealed that most of the respondents have a high school education level. Still, most of them do not have sufficient 


\section{Epidemiology and Society Health Review $\mid \mathbf{E S H R}$}

knowledge about exclusive breastfeeding because of another factor, namely, parent's culture in breastfeeding.

A total of 35 respondents $(62.5 \%)$ in Jatimulyo Village have multigravida, and 27 (48.3\%) had a moderate level of exclusive breastfeeding knowledge. The result of research in Jatimulyo Village shows that most respondents with primigravida have a moderate level of knowledge due to lack of experience. Previous research shows that 18 mothers $(54.54 \%)$ with multigravida have a level of knowledge and awareness, and 13 mothers $(48.18 \%)$ do not have the awareness to practice exclusive breastfeeding with a value of $0.043<0.05$. It means that there is a relationship between parity and the level of awareness in breastfeeding (13). Based on data on breastfeeding patterns in Jatimulyo Village, 24 respondents $(42.9 \%)$ have a predominant pattern; 21 respondents $(37.5 \%)$ have exclusive breastfeeding patterns, and 11 respondents (19.6\%) have a partial pattern in breastfeeding. It indicates that the mother's exclusive breastfeeding awareness is low and has not met the government targets.

Based on the collected data from Jatimulyo Village, respondents of productive age do not always apply exclusive breastfeeding patterns. They also apply predominant patterns due to lack of motivation from health workers and families, and the place of delivery. Typically, respondents who give birth at the primary health center will be motivated to practice early initiation breastfeeding and to complete the exclusive breastfeeding.

Adequate education is the basis for developing insight of people as well as produces motivation on practicing knowledge to attitude and practice. Mother with low education causes they slow in adopting new knowledge, including about breastfeeding (14). Most respondents or a total of 30 respondents $(53.6 \%)$ in Jatimulyo Village have a high school education level, and $14(25 \%)$ of them have predominant breastfeeding patterns. Although their education is quite high, some of them lack experience in breastfeeding, lack of motivation from health workers and families, and cultural influences. However, only 14 (25\%) respondents with high school education practice the exclusive breastfeeding pattern because they have the motivation and ability to absorb the information provided by health workers.

Meanwhile, $4(7.1 \%)$ out of $5(8.9 \%)$ respondents with low education level or primary school level have partial patterns due to lack of exclusive breastfeeding knowledge. Then, four respondents $(7.1 \%)$ with university education level have the exclusive breastfeeding pattern. Many highly educated mothers manage to give exclusive breastfeeding and open and absorb information easily. Accordingly, they know more about the importance of exclusive breastfeeding. This is in line with Mardeyanti's research in Yogyakarta that found a link between nursing mothers' education and exclusive breastfeeding. It was concluded that low maternal education level increases the risk of mothers not giving exclusive breast milk to their babies (15).

Our result shows that respondents most widely apply the exclusive pattern with primigravida because they have broader information and knowledge about exclusive breastfeeding, health workers, and family support. It is in line with Mabud's research, which showed a relationship between parity and the breastfeeding p-value of $0.04<0.05$ (16).

Based on the result of research in Jatimulyo Village, Petanahan Sub-district, the data obtained from the chi-square test shows a p-value of $<0.002(<0.05)$. The standard for accepting the hypothesis is if the p-value is $<0.05$, then $\mathrm{Ha}$ is accepted. It indicates the relationship between exclusive breastfeeding and breastfeeding patterns with a correlation value of 0.499 . The current study shows a relationship between exclusive breastfeeding knowledge and breastfeeding patterns in Jatimulyo Village. The result of research in 


\section{Epidemiology and Society Health Review $\mid \boldsymbol{E S H R}$}

Posyandu in Jatimulyo Village shows that $12(21.4 \%)$ respondents with a moderate level of knowledge have exclusive breastfeeding patterns; 20 respondents $(35.7 \%)$ have a predominant pattern, and eight respondents (14.3\%) apply partial breastfeeding pattern. Therefore, the higher level of exclusive breastfeeding knowledge, the higher motivation to practice exclusive breastfeeding. This finding is in line with Mabud's research, which shows the relationship between knowledge and exclusive breastfeeding (16). However, the success of exclusive breastfeeding is also affected by several factors such as mother's attitude, family support, information from health workers, and culture.

\section{CONCLUSIONS}

Most of the respondents in Posyandu of Jatimulyo Village are 26-30 years old with a high school education level and in the second parity. The knowledge of respondents in Posyandu of Jatimulyo Village, Petanahan Sub-district about exclusive breastfeeding, is moderate. This can be one of the factors in the failure of exclusive breastfeeding. Most of the respondents in Posyandu, Jatimulyo Village, Petanahan Sub-district, have predominant breastfeeding patterns. It indicates that the failure of exclusive breastfeeding is still high. There is a relationship between the level of mothers' knowledge about exclusive breastfeeding and breastfeeding patterns in 6-month-old children in integrated health services post of Jatimulyo Village, Petanahan Sub-district.

\section{Authors' contribution}

HS, WR, \& JD; Study Design. HS \& JD; Data collection. HS, WR, JD\&SG; Data analysis and revisions for important intellectual content. HS; Manuscript writing. All authors read and approved the final manuscript.

\section{Funding}

This research was financially supported by Sekolah Tinggi Ilmu Kesehatan Muhammadiyah Gombong, Central Java, Indonesia

\section{Acknowledgments}

We acknowledge the supported Research Department of Sekolah Tinggi Ilmu Kesehatan Muhammadiyah Gombong made this research done well.

\section{Conflict of interest}

There is no conflict of interest in this research.

\section{REFERENCES}

1. Putri R, Illahi SA. The Relationship between Breastfeeding Patterns and the Frequency of Illness in Infants. J Issues Midwifery. 2017;1(1):30-41. (in Indonesian)

2. Indonesia Ministry of Health. Guidelines for Implementing World Breastfeeding Week. Jakarta: Kementrian Negara Pemberdayaan RI; 2010 (in Indonesian)

3. Amran Y, Amran VYA. Description of Mother's Knowledge of Breastfeeding and its Impact on Exclusive Breastfeeding. J Kesehat Reproduksi. 2013;3(1):52-61. (in Indonesian) 


\section{Epidemiology and Society Health Review $\mid \boldsymbol{E S H R}$}

4. The Indonesian Ministry of Women's Empowerment and Child Protection (PPPA). Profile of Indonesian Children 2018. Jakarta: PPPA and BPS; 2018. (in Indonesian)

5. Kebumen District Health Office. Kebumen Health Profile. Kebumen: Kebumen District Health Office: 2018. (in Indonesian)

6. Hani RU. Relationship of husband's support to the success of exclusive breastfeeding to primipara mothers in the work area of Pisangan Puskesmas. Thesis. Universitas Islam Syarif Hidayatullah; 2014. Available from: http://repository.uinjkt.ac.id/dspace/bitstream/123456789/25664/1/Ratu Ummu Hani fkik.pdf. (in Indonesian)

7. Utami NT, Abdullah T, Sarake M. Factors Associated with Exclusive Breastfeeding in the Work Area of Birobuli Primary Health Center. Makasar: Faculty of Public Health, Department of Bio-Statistics, Universitas Hasanudin; 2012. (in Indonesian)

8. Institute for Health Research and Development Agency. Report on the Central Java Province, Indonesia Basic Health Research 2018. Semarang, Litbang Kesehatan Jawa Tengah; 2019. (in Indonesian)

9. Rahmawati NA, Tyastuti S, Widyasih H. Relationship between the level of knowledge about exclusive breastfeeding and early breastfeeding. J Involusi Kebidanan. 2014;4(7):53-66. (in Indonesian)

10. Hartatik T. The Relationship between Mother's Knowledge and Attitudes with the Exclusive Gifting in Gunungpati Village, Gunungpati District, Semarang City in 2009. UNNES; 2009. (in Indonesian)

11. Wowor M, Laoh J, Pangemanan D. The relationship between knowledge and attitude with exclusive breastfeeding for breastfeeding mothers at Puskesmas Bahu, Manado. J Keperawatan UNSRAT. 2013;1(1):1-7. (in Indonesian)

12. Wadud MA. Relationship of mother age and the parity with exclusive breastfeeding in 0 6 months baby in Pembina Health Center of Palembang year 2013. 2014 [cited 2020 Jun 26]. Available from:

https://www.academia.edu/9755086/HUBUNGAN UMUR IBU DAN PARITAS DENGAN PEM BERIAN ASI EKSKLUSIF PADA BAYI BERUSIA 06 BULAN DI PUSKESMAS PEMBINA PALEMBANG TAHUN 2013. (in Indonesian)

13. Lestari AR, Nawangsih, Edi UH. Relationship between the level of knowledge about exclusive breastfeeding and parity of breastfeeding mothers with exclusive breastfeeding at the Sewon II Public Health Center in Bantul in 2013. UNISA; 2013. (in Indonesian)

14. Yolanda D. Relationship between education and mother's knowledge level about breastfeeding with exclusive breastfeeding. J IImu Kesehat 'Afiyah. 2015;2(1):1-7. (in Indonesian)

15. The relationship between work status and maternal compliance provides exclusive breastfeeding at RSUP Dr. Sardjito Yogyakarta. Universitas Gadjah Mada; 2007. (in Indonesian)

16. Mabud N, Mandang J, Mamuaya $\mathrm{T}$. the relationship between knowledge, education, parity and exclusive breastfeeding in Puskesmas Bahu, Malalayang Sub-District, Manado. J IIm Bidan. 2014;2(2):51-56. (in Indonesian) 
Epidemiology and Society Health Review $\mid \boldsymbol{E S H R}$ 